\title{
Sindhi Civil Society: Its Praxis in Rural Sindh, and Place in Pakistani Civil Society
}

\author{
Ghulam Hussain1, Anwaar Mohyuddin'1*, Shuja Ahmed² \\ ${ }^{1}$ Department of Anthropology, Quaid-i-Azam University, Islamabad, Pakistan \\ ${ }^{2}$ Pakistan Study Centre, University of Sindh, Jamshoro, Pakistan \\ Email: mahesarg@gmail.com,
}

Received 26 June 2014; revised 24 July 2014; accepted 12 August 2014

Copyright (C) 2014 by authors and Scientific Research Publishing Inc.

This work is licensed under the Creative Commons Attribution International License (CC BY). http://creativecommons.org/licenses/by/4.0/

(c) (i) Open Access

\begin{abstract}
Sindhi Civil Society and NGOs working in rural Sindh have a dialectical relationship with each other and with rural communities, particularly peasants and marginalized rural ethnic groups. In this article, the nature and structure of Sindhi civil society vis-à-vis their efforts to differentiate themselves from Pakistani civil society and ethnically hegemonic NGO-structuring, resultant perceived marginalization of Sindhi civil society and NGOs working in rural Sindh, have been classified, explained and analyzed in the light of secondary and primary data. Effort has been made to locate historical intersection points between the spawning of NGOs and the origin of modern Civil Society networks, and relate it to Sindhi civil society in global perspective. This paper is the result of the analysis of secondary data validated through an ethnographic study conducted in Naon Dumbaalo and Chamber area of District Badin, and urban area of Qasimabad at Hyderabad District in Lower Sindh.
\end{abstract}

\section{Keywords}

Sindhi Civil Society, NGOs, Development, Ethnic Marginalization

\section{Introduction}

Although, the notion of civil society is as old as the "Politics" of Aristotle (Cohen, 1994; Aristotle, 1252), and spatially as diverse as its definition by Ibn-i-Khaldun. Yet, in definition and practice it remains as ambiguous as it was in the past. The term "civil society", however, in its present form, was first defined by Alexis de Tocqueville who presented it as the "voluntary, non-political social organizations that strengthen democracy preventing a tyranny of the majority" (Stefan, 2008; Keane, 2009). Ernest Gellener, on the other hand, differentiated be-

${ }^{*}$ Corresponding author. 
tween oppressive kinship-based, religious and ritual-defined organizations and the civil society in which civic sense prevailed. Gellener believes that pluralism of the sort which lacks in civic sense and egalitarian values cannot be called as the characteristic of civil society (Keane, 2009). Whereas, some in Eastern Europe, such as Václav Havel, have defined civil society as the "sphere of civic associations threatened by the intrusive holistic state-dominated regimes of Communist Eastern Europe" (Powell, 2007). Oxford dictionary defines civil society as, "Society considered as a community of citizens linked by common interests and collective activity." Sociologically, civil society is neither a class, nor a group of well-educated citizens, though it may consist mostly of well educated, and responsible citizens.

Hence, there can never be a single definition or interpretation of the civil society because of the fact that its structure and functions vary both spatially and temporally. Yet in a somewhat broader sense, it can be said that civil society is based on liberal ideology and various "freedoms" is meant, understood and acted differently by different groups, sections and organizations of the society. Usually, some groups or organizations within civil society at some points favor socialist changes, whereas others favor capitalist changes. Thus, civil society is not merely the follower of capitalist liberalist agenda. It could include any group even Marxists or communists that label it as essentially a capitalist hoax. For others such as Bryan Turner, the notion and structure of civil society are Eurocentric in its essence. Keane explains it thus:

The western concept of civil society is based on in individualism; thus, the West assumes there is "no established tradition of legitimate opposition to arbitrary governments in Islam" because Islam is "devoid of individual rights and individuality”. However, the West ignores similarities between Islam, Christianity and Judaism. Furthermore, the West accepts Islam's lack of social capital as the cause of its political instability and fails to examine other possibilities... Civil society is instead a series of informal relationships based on religious, familial and clientele connections that can and do exist under undemocratic governments, for they are entirely beyond the government's sphere (Keane, 2009).

Civil society, thus can be loosely defined by combining both Western and Middle-Eastern definitions by which it could be formed in both democratic and undemocratic governments (Keane, 2009). John Keane, thus, defines civil society in the following manner.

"Contrasted with government, civil society meant a realm of social life-market exchanges, charitable groups, clubs and voluntary associations, independent churches and publishing houses-institutionally separated from territorial state institutions. This is the sense in which civil society is still understood today: it is a term that describes and anticipates a complex and dynamic ensemble of legally protected nongovernmental institutions that tend to be nonviolent, self-organizing, self-reflexive, and permanently in tension, both with each other and with the governmental institutions that "frame", constrict and enable their activities." (Keane, 2009).

\section{Methodology and Theoretical Framework}

This research article is based on an ethnographic fieldwork, and qualitative content and discourse analysis of the views, theories and notions about Civil Society, NGOs and their role in the development. The data were collected in Naon Dumbaalo and Chamber area of District Badin, and urban area of Qasimabad at Hyderabad District in Lower Sindh. Yet much of data have also been collected through secondary resources to relate the perceptions of Sindhi social activists about Sindhi civil society with the meaning and role of Civil Society and NGOs as perceived by various social activists, social scientists and theorists around the globe. Hence, it's a kind of hermeneutical enquiry as well as an explanatory note on the nature of Sindhi and Pakistani civil society and NGO sector. Although no particular theory has been applied here as the analytic touchstone to evaluate civil society and the role NGOs, it is largely a post-developmental and critical enquiry implicitly influenced by the theories of Jürgen Habermas on "public sphere” his theory of "communicative action" (Habermas, 1987) and Arturo Escobar's $(1995,1997,2012)$ critique of development. The elaborative ideas of Desai (1979a) about V. Lenin's “Two-stage theory of Revolution”, and the general Marxist stance of Slavoj Zizek (2012), and Eagleton (2011), neo-Marxist thinkers, has also been given weightage while analyzing the role Sindhi Marxist social activists.

\section{Results and Discussion}

NGOs, along with Print and Mass Media, Social media are the prime vehicles of the so called civil society in 
today's globalizing world. NGOs, as they exist today, are believed to be a byproduct of the failure of the state, centralized governments and traditional social institutions to cater to the needs and issues of common people. (Bagci, 2003). NGOs further evolved though the complicated interaction between local cultures and traditions, local and international ideological trends, and the policies and agendas of global donor agencies (Ahmed, 2009).

Looking retrospectively, NGOs were, in fact, the earliest human organizations, particularly peasantivist communes, formed on the principle of mutual self-help and protection. "First, there were farmers" organizations as in Japan in 1868... Traditional self-help associations also have a long history in Africa and Asia” (Ahmed, 2009). Hence, earliest Community Based Organizations (CBOs) which are informally organized, over the years with modernization and increasing globalization, were replaced by formal, highly organized, registered, bureaucratized, and technically sophisticated expert-led NGOs.” (Bagci, 2003).

The use of the phrase "non-governmental organization" was introduced by United Nations Organization in 1947, in its Article 71, and defined it as such organizations which are neither governmental, nor belong to member states, and explained its functioning as the mediatory consulting bodies that play major role in the sustainable development of societies and communities. The World Bank's Operational Directive on NGOs (No.14 70 August 1970) defined the term of "NGOs" as "The groups and institutions that are entirely or largely independent of governmental and characterized primarily by the humanitarian or cooperative, rather than commercial objectives” (Bagci, 2003).

Spawning of NGOs in the form of "development sector", its perpetuation as the "aid industry" was spurred by the worldwide economic crises and oil shocks of 1973. It was also spurred by the western-centric or Eurocentric self-proclaimed role as the patrons of the world, the civilized nations whose task was formally explained by Harry Truman in 1949 in his concept of "fair deal" that initiated a "new era of understanding and management of world affairs, particularly those concerning the less economically accomplished countries of the world" (Escobar, 1995: p. 3). American-led western development project that started off under the auspicious patronage of U.N.O and its subsidiary agencies, particularly the World Bank, IMF, WTO, UNICEF, was very much econo-centric and techno-centric, not to mention of its West-centric bias towards the so called developing, or third world countries of the global South (Escobar, 1997).

Hence, the role of NGOs in development was questioned by post-devleopmentalists that proclaimed the failure of "trickle-down effect" approach, and resultantly, participatory development approach was introduced in the NGO sector in 1980s. The role of the state as the prime institution to ensure the welfare and development of societies was also questioned. The incapability of the welfare state system to deliver created a vacuum for NGOs to fill in that gap. The fall of the Soviet Communist system and the increasing globalization during 1980 and 1990s, further promoted and brought NGOs as well as transnational INGOs to the front stage at global level (Ahmed, 2009; Bagci, 2003). Hence, the failure of the state to address the issues of underdevelopment resulted in further mushrooming of NGOs to channel the bilateral and multilateral development funds.

NGOs were perceived to be a panacea for much of the ills that affect underdeveloped countries, and were supposed to do development in a way very different from the way the state pursued these objectives. They were thought to be participatory, community-oriented, democratic, cost effective, and better at targeting the poorest of the poor. However, in recent years, the halo of saintliness around NGOs has almost disappeared, and there is wide acknowledgement of the inability of NGOs to deliver what was expected from them (Zaidi, 1999).

Learning from the failure of neoliberal capitalist agenda of the West to modernize or rather civilize the poor and ignorant South, and also to sustain its own vested interests they started focusing on humanitarian issues, environmental and ecological issues, human rights and community based sustainable development of the underdeveloped. They established the World Social Forum to counter the World Economic Forum that viewed development monolithically through the economic lens by merely focusing on economic growth.

Gandhi Asharam at Banaras that was established in 1927 was probably the first NGO-type organization of the Sub-continent. It aimed at job creation for the native population in the British regime (Ahmed, 2009). In the context of Islam, the Madressah system as a kind religious NGO that not did impart religious and moral education, but also provided jobs for the religious scholars, preachers and sometimes, took to social welfare and community development activities as well. "To control these associations, the colonial authorities introduced the system of registration under the act of cooperative societies. Each society was required to give constitution and bylaws and maintain financial accounts." (Ahmed, 2009). Those earlier NGOs were no less than role models as far sincerity and lack of financial and moral corruption was concerned. They were committed to their respective 
missions. The issues of mismanagement and corruption emerged when new type of western-oriented NGOs emerged during 1970s. Apart from working on western-led econocentric and technocentric agenda, these NGOs turned out to be less community-based, and more like familial nepotistic business organizations surviving on the internal embezzlement of donations and funds given directly to them from international donors, such as World Bank (Ahmed, 2009).

Running of NGOs like family organization, business or capitalist enterprise is evident from the jargon that is used while contracting partners or so called "stakeholders", engaging in self-styled "community intervention", and implementing foreign funded projects. Like elsewhere in the world, foreign-funded NGOs in Pakistan often speak of development in terms of partnership with stakeholders (government, IFIs, INGOs and other NGOs), and not in terms of cooperation with CBOs, or for CBOs. They speak about the success of the project, not about the political, economic and social empowerment of people. The fact worth mentioning here is that International Financial Institutions (IFIs), that provide funds to local NGOs are themselves funded by MNCs and politically supported by the capitalist bloc of G-20 countries (Ahmed, 2009; Bagci, 2003; International Finance Corporation, 2011). In Pakistan, these NGOs have provided personal economic and political refuge to civil society activists of diverse political, economic, social, religious and cultural credentials. Ayesha Siddiqa, a prominent social activist and an intellectual of international acclaim has described the nature of Pakistani civil society thus:

What does the city have in the name of civil society except a couple of corrupt NGOs pushed by certain state functionaries pretending to represent an alternative voice? The tragedy of liberalism in Pakistan (even larger South Asia) is that it is now mainly confined to drawing rooms and Twitter. It is cute to see people taking risks on social media and then rising to prominence due to threats on Facebook or Twitter. The fear of violent reaction in real life is too intense for many to do more (Siddiqa, 2014).

After the failure of successive governments in 1990s to deliver to the masses, the failure of development sector to deliver has also got exposed to every sensible person in Pakistan. Rampant corruption within social sector/development sector has recently prompted government to put certain checks and balances on NGOs that are run on funds from foreign donors. Economic Coordination Committee (ECC) of the federal cabinet approved policy in late 2013 by which it has been made legally obligatory for NGOs to disclose "sources of funding, details of proposed projects, areas of work, and details of the geographic location of the projects" (Ahmed, 2013). Given the fact that governmental bureaucratic institutions themselves are no less corrupt than NGOs, any governmental efforts to monitor and audit NGOs could hardly be expected to live up to their duties. Nevertheless, it is the step that would, to some extent, make NGO's internal administrative files and workings accessible to the media for general auditing through masses. It would have been still better if the government would have allowed local non-funded voluntary organizations or committees of communities to monitor and audit NGOs finances and evaluate its success in their respective localities.

\section{Pakistani Civil Society as Defined by Sindhi Civil Society Activists}

Very much like Siddiqa (2014) who has sarcastically depicted the general picture of development sector in Pakistan, Sindhi social activists have critiqued Pakistani civil society and NGO-led development in Pakistan from ethnic perspective by lampooning it as ethnically discriminatory and depoliticizing in nature. Sindhi civil society and Sindhi social activists, however, differentiate themselves from Pakistani civil society on ethnic grounds. For them NGOs in Pakistan are ethnically hegemonic organizations serving the interests of Pashtun and Punjabi ethnic groups and Pakistani civil society. For them Sindhi civil society is a marginalized entity and is distinctively different group from the dominant Pakistani, Punjabi and Urdu civil society. They also differentiate themselves from those social activists and NGOs that work in Sindh largely in urban areas Sindhi civil society differentiates itself from the Urdu and Pakistani civil society on political and ethnic grounds. They believe that Pakistan civil society is ethnically biased towards Sindhis and other marginalized ethnicities of Pakistan. To prove their point Sindhi ethno-nationalist activists allude to the hierarchical structure of NGOs monopolized by certain ethnic groups. Country directors and all major decision-making and executing personals of key civil society organizations in Pakistan are politically affiliated with major feudalist-industrialist parties of Pakistan or with local ethno-nationalist parties (Shah, 2014). Zulfiqar Shah, a Sindhi civil society activist and an ethno-nationalist peasant activist ${ }^{1}$, maintains that:

${ }^{1}$ Zulifqar Shah has been a proactive member of Sindhi civil society during the last decade. He has also led a peasant march in 2010, for land reforms in Pakistan, and had also established a civil society organization, Institute of Social Movements (ISM). 
In Pakistan, the leadership of development and rights based initiatives is primarily dominated by ethnic Punjabis, together with their ethnic Urdu speaking as well as to some extent their sycophants from Hazara division in Khyber Pakhtunkhuwa. The visible participation of Sindhi and Baloch civil society leadership at the Central level is as unimaginable as their visibility in Pakistan's military and civil bureaucracy and the security fraternity... ethnic Punjabi, Urdu, and Hindko speaking are well connected with the Pakistan's security establishment; a few Sindhis are also at the outer level of engagement with the security agencies. The civil society leadership of Sindh and Baluchistan that have dissent with the establishment, are against the military's anti-people role, or are critics of the security establishment backing extremism are discouraged, unemployed, persecuted, and trapped through the existing top level or second tier leadership of the civil society in Pakistan (Shah, 2014).

Shah (2014) maintains that the network of five major civil society organizations controlled by Punjabi, Urdu and Hidko-speaking executives, is dominating and controlling the middle class discourse and the development discourse in Pakistan. He explains that these five major Pakistani civil society networks work in the name of several social problem based themes, such as, land rights, bonded labour, human rights, gender equality, political rights, governance, minority rights, social security issues, youth networking, Global South Initiatives, Pakistani, South Asia and World activism of the left, flood relief projects, disaster management, community mobilization, election monitoring, honor killing, bonded labor rights and several other issues and perceived problems. (Shah, 2014). Zulfiqar Shah is very equivocal in his assertion about the essentially non-Sindhi and ethnically biased structure and function of Pakistani civil society and NGOs. Shah has alluded to the alleged networking within social sector at Pakistan level, such as National Rural Support Program (NRSP), Rural Support Program Network (RSPN), International Dalit Solidarity Network (IDSN) etch, as the deliberate attempt by the establishment to keep the really marginalized voices suppressed. He writes:

The art of networking is the modus operandi through which the powerful Punjabis, Urdu speaking and Hindko speaking capture the leadership of the civil society of Sindh, Siraiki South Punjab, Pakhtunkhuwa and Balochistan. It is a strange coincidence that a large number of retired military commissioned officers have registered and are running their own NGOs... Most of the Pakistan level civil society leadership is Punjabi and is closely or remotely family relations with the serving or retired senior military officials. They primarily establish their networks of community based organizations of Sindhis, Balochis and Sirakis; manage to elect themselves as their leader; and start owning their initiatives and market them to the donors. Besides receiving funding, they start their networking with the world outside Pakistan, so that the image, feel, perception and the reality of Pakistan's internal society they want to show to the others may not contradict the overall policy of Pakistan. Besides, by doing this, they undertake a triple advantage of acquiring central leadership role of being civil society, become the people's diplomats outside Pakistan and receiving larger international funding (Shah, 2014).

Concerns and scruples of some Sindhi social activists notwithstanding, rural Sindh is, by and large, an sphere of social activism for Sindhi civil society and therefore, the issues that they usually focus relate to rural society, peasant communities, fisher folk, village culture, agriculture, building of dams, water issues and human rights related to honor killing, tribal feuds, casteism and environmental issues. Viewing Sindhi civil society and Sindhi peasant activism from internally, in Sindh actual living peasants, agricultural workers, bonded laborers and sharecroppers are conspicuously dumb and do not come forward to demand their rights to have land and decent life. Neither a substantial number of middle peasant-proprietors, small farmers and landowners have been in the forefront of peasant rallies and movements. Demands of peasant and rights are mainly defined, propagated and channeled by a network of urban-based peasant activists which form the bulk of so called Sindhi civil society, and NGOs working in rural areas of Sindh.

\section{Structure of Sindhi Civil Society}

It would be enlightening to ponder a bit over the structure of the Sindhi Civil Society itself as perceived by Sindhi social activists. Zulfiqar Shah, being focused more on the critique of Pakistani civil society, did not shed much light on the internal structure of Sindhi civil society. That job has been partially done by Ali Qazi. Qazi (2013), a prominent Sindhi mass media intellectual has classified Sindhi civil society into four categories.

1) Intellectual activists

2) Political worker activists 
3) Media experts and opinion makers

4) Silent observers

Ali Qazi maintains that, it is the task of intellectual activists, political workers and media experts to bring to the fore silent observers, which is the largest category, that merely debate and discuss real life issues in their everyday life but do not play any active role in their solutions (Qazi, 2013). Sindhi Civil Society, however, can also be classified regionally and spatially based on their area or field of activism. It provides for the "public sphere" in Habermasian sense (Dahlberg, 2005) for Sindhi people to have dialogue and debate over, and critique each other, other ethnic groups, governmental and state policies and the development sector. Roughly, and in suggestive manner, to further elaborate upon it, that public sphere can be classified as:

1) Local (town-based and village associations)

2) Virtual (social media networks like, international radio Voice of Sindh, Satellite Sindhi channels such as KTN, Sindh TV, social student alumni organizations such as QSF, Facebook, website-based advocacy organizations)

3) Regional

a) Upper Sindh (SRSO, Readers Forum, CSS Coaching centres, Shah Nawaz library)

b) Lower Sindh, (Qasimabad based NGOs)

c) Rural and, or urban, (based on ethnic and thematic differences); Civil society of interior Sindh can also be differentiated on the basis of field of activity and spatial-geographical region. Field of activity and social sphere of Urdu-speaking population of Hyderabad is totally different and urban-centered focused largely on the issues of Urdu-speaking population, whereas NOG offices located in Qasimabad Hyderabad which is essentially a Sindhi-speaking Talluka, is rural-centric, sympathetic to Sindhi ethno-nationalists and anti-feudalistic in approach.

d) Provincial, (SGA, Sindhi Adabi Sangat)

4) National (Islamabad based Mehran Students Council, Quaidian Sindh Forum)

5) International or transnational (Sindhi Association of North America SANA, World Sindhi Congress WSC ${ }^{2}$, World Sindhi Institute WSI ${ }^{3}$ ).

\section{Eternal Union: Sindhi Civil Society, NGOs and Ethno-Nationalist Parties}

In broader sociological sense, all social, political, cultural and intellectual activists, including leftists and Marxists can be classified as constituting civil society. There are certain specific characteristics of Sindhi civil society that keep it distinct from the Pakistani civil society or any other national civil society forum. Sindhi civil society, although ideally hetro-national in character believing to be multicultural is, in fact, essentially an ethno-nationalist aggregate of well-educated Sindhi activists. A leading Sindhi civil society activist, Jami Chandio, maintains that "All political experiments in Pakistan have failed" (Chandio, 2013). Reasoning on the similar lines, most of the Sindhi civil society activists mistrust state and believe that the state has failed to deliver marginal and minority ethnic groups. Hence their stance is in line with all leftists and ethno-nationalists that are intermeshed and interlinked with the civil society, rural-based NGOs, and with social and peasant activists in Figure 1 .

As things stand, Sindhi civil society is no more than an unorganized gathering of likeminded NGOs and social activists. Although these NGOs and civil society activists are dispersed throughout Sindh, most of them operate from Talluka Qasimabad of Hyderabad District. Every year, several programs and seminars are arranged by Sindhi civil society activists on the role, importance and achievements of civil society, development sector and Sindhi nationalism.

\section{Action Mechanism of Civil Society Activists}

Sindhi Civil Society, in fact, is the pragmatic and processual platform in which programs, purposes and agendas shift and some sort of consensus is developed to bring about social changes without endangering their perceived

\footnotetext{
2"WSC is based in the UK, USA, Canada, and Sindh and is one of the most prominent human rights advocacy organizations for Sindh and Sindhis. The main objective of WSC is to create a better understanding within the international community about the persecuted status of Sindhis in Pakistan and about the Sindhi people's struggle for human rights, including the right to self-determination. WSC is a registered company in the UK and the USA, and is organized to carry out non-profit activities. For more information, visit www.worldsindhicong ress.org” (World Sindhi Congress, 2014).

3،"The World Sindhi Institute (WSI) is a progressive organization committed to socio-economic, political and environmental justice for Sindh and other oppressed peoples and nations through peaceful and nonviolent means” See http://www.worldsindhi.org/
} 


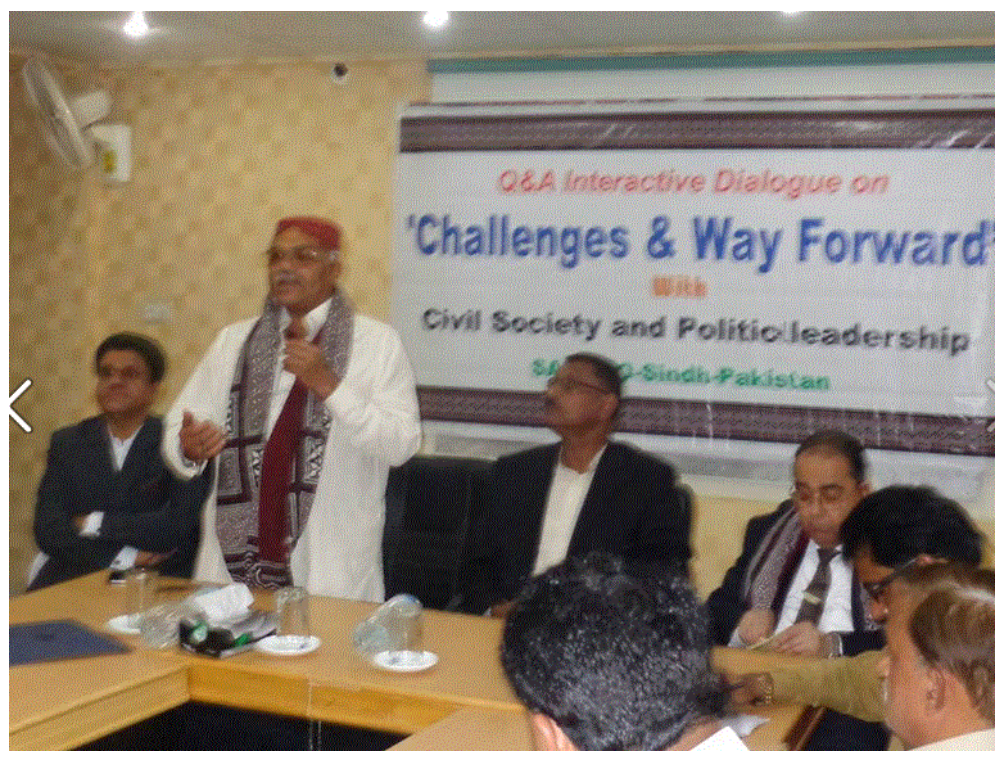

Figure 1. Local ethno-nationalist political leader addressing the civil society-cum-NGO gathering to have dialogue on the role of political leadership and civil society. Source: Author (2013).

Sindhi civil society. It's a reformist platform, which looks for solutions, the way NGOs often do, that is, through SWOT analysis of the situation though done in an informal way. Theirs is the game of practice limited to intracity, closed door activities; nothing is written, not much research is done on their social activities, and often take each other's activist-credentials for granted, and believe that they know each other, their organizations and their multiple memberships very well. They depend on post-hoc reasoning to predict success or the failure of their programs. They hold few rallies and sit-ins, arrange seminars and workshops in NGO offices, or at a hotel, and on the basis of that socio-political action, assess the success and impact of future rallies and relevance of their socio-political agendas to prevailing conditions. Most of their criticism and deductions are apologetic and self-alleging, and often put the burden of their collective failures on the other party or organization without concretely devising further road map for further social and political action. Hence, their activism often ends up without achieving their avowed goal and leads to further segmentation, differentiation and divisions within Civil Society Activists.

Despite their limited capacities to influence provincial and national policies, Sindhi Civil Society has nevertheless evolved two distinct internalsocio-political discourses that prevail among the civil society activists and developmentalists. In public meetings in programs and while making speeches they pose like true humanitarians and make believe that things are going good for the common people, yet in private sittings, their stance is quite the opposite of what they proclaim publicly. In off-the-record meetings, they confess the hypocrisy that is at the root of development sector, they condemn NGOs as a failed practice, that it's all about business and money making, that the whole society, including them, is pathologically corrupt, and that there is no way out of it. They also condemn so called ethno-nationalist Sindhian activism as dishonest and lacking in commitment. Once such meeting, in which the researcher participated as an unwelcome guest, confronted an engaged anthropologist. That so-called anthropologist was one of the most enthusiastic participant who stressed the need for participatory research and community-level engagements, later after the meeting was over in informal gathering confessed that, practically and in reality, community welfare is of secondary importance, and that NGOs are actually run as personal businesses, and the civil society activists primarily aim at the money-making and personal glory. Another host belonging to a well reputed labour organization pessimistically confessed that "we Sindhis as a nation and as social or peasant activists have miserably failed and there is no light visible at the end of the tunnel. He regretted that fact that, "they are bound to toe the line of western donors or donor led NGOs" (Anonymous, 2013).

Both leftists and ethno-nationalists, which usually lack in economic sources, are in commensal relationship with other civil society organizations and NGOs, in which NGOs, out of vested interests, fund rallies and pro- 
tests that suit leftist agenda. Leftist and ethnonationalist activism, in turn, serves as an instrumental factor for NGOs to buy further funds from capitalist donors. In that sense, some peasant activists are doing a dually hypocritical job. They are tactically using foreign donor's money indirectly to finance their non-project based activism, yet, in process, helping local NGOs to get more development funds for newly problematized projects.

In interior Sindh, large rallies and demonstrations are held and planed by NGOs and voluntary organizations; and in collaboration with ethno-nationalist political parties and independent civil society activists, programs and agendas are set up. Social media and information technology have greatly facilitated their coordination to successfully arrange meetings, hold seminars and stage demonstrations. It's a team work in which many organizations participate. Tasks are assigned to each member and representative to ensure the success of the event. Certain NGO members, for instance, are given task to ensure participation of people from within the area of influence; others would ensure transport or meals etc.

Non-cooperating anti-block, however operates from some other platform. Yet, on the whole, usually any single event of social activism engages a sponsoring international funding agency, its leading agent NGO, international and national human rights watch-dogs, and two to three NGOs working on specific social problems. Guest speakers invited could be political party leaders, as well as renowned intellectuals. In short, there is the whole organized network of social activists, members of which work in different NGOs, associations and political parties. Their collective effort, however, seem to have no solid grounding in the masses or local communities. Hence, their activism is largely dependent on the support of local leaders from within communities. In a civil society meeting, to organize a rally for land reforms, for instance, Manu Bheel, a victim of bonded labour and feudal oppression, ensured the highest number of Bheel participants than any NGO or social organization. Similarly, Parkari Kolhis at Naon Dumbālo and Chamber, at the call of their Kolhi activists, have always volunteered to lead the rallies in Chamber, Tando Ghulam Ali, and Tando Allahyar. It is not only a strong indicator and proof of the power of community and the leadership from within the community that should be further boosted, but at the same time shows weakness and lack of involvement and penetration of outside activists within communities. Although some of the individual members that make up civil society and struggle for the cause of Sindhi nation and marginalized sections of society, are sincere and contributing for welfare and uplift of rural Sindh, yet the defeatist and pessimistic statements of most of the civil society activist are in fact proofs of civil society's own impotency and incapability to serve as the major agent of social transformation in rural Sindh.

\section{Marxist Revolution, Civil Society and Anthropology of Sindhi Peasantry}

Eric Wolf's anthropological work, "Peasant Wars of the Twentieth Century" has given a profound account six peasant rebellions and struggles against imperialistic forces. Desai has highlighted the Wolf's account of "the heroic struggles of the peasantry of Vietnam... which was described by the US Military as "ragged little bastards in black pajamas", confronted and defied in an unparalleled manner the mightiest military machine in history. This peasantry, which was assumed to be the bearer of tradition and obstacle to modernization, was becoming a force which was shattering not merely the socio-cultural and politico-economic structure of Vietnam itself, but triggered some of the most profound movements in the very heart of the bastion of imperialism." (Desai, 1979a, 1979b: pp. 761,726). Wolf has emphasized and traced the historical causes behind peasant struggles, the analytic tradition which was not emphasized much in Anthropological enquiries of peasant communities. Following the same line, Kolhi peasant exploitation and activism have been evidenced to have deep historical, ethno-religious and colonial roots.

Concluding on the nature of peasant revolution and inevitable commodification of land in subsistence economies of the colonized world, Wolf writes that if the land:

“... had to become a commodity in the capitalist market... it has first to be stripped of these social obligations'. This was achieved either by force, through colonization of new lands or indirectly accomplished by furthering the rise of 'the strong and sober entrepreneurs within the peasant communities, who could abandon their ties to neighbors and kin, and use their surpluses in culturally novel ways to further their own stand in the market'. The spread of capitalism necessarily produces a revolution of its own. This revolution from the beginning takes the form of an unequal encounter between the societies which first incubated it and societies which were engulfed by it, in the course of its spread. The contact between the capitalist center, the metropolis, and the pre-capitalist or non-capitalist periphery is a large-scale cultural encounter, not merely an economic one.” (Desai, 1979a, 1979b: pp. 763-764). 
Wolf, commenting on peasant rebellions, concludes that,

“The West disintegrated the old fabric but initiated distorted new subordinated ones shaped by its own requirements. This was new experience uprooting the entire past and necessitating the creation of a new social order, which will eliminate the combined ravages of disintegrated old societies and destroy new forms of exploitation and oppression... Where previously market behavior had been subsidiary to the existential problems of subsistence, now existence and its problems became subsidiary to market behavior.” (Desai, 1979a, 1979b: p. 763).

From the perspective of a two-stage theory of revolution, as stipulated by V.Lenin, bourgeoisie-democratic revolution of the peasantry against feudalism should precede the socialist revolution against the capitalists. The bourgeois-democratic revolution is the preparatory stage for the socialist revolution. Bourgeoisie revolution or the civil society led revolutionary or reformist change is not the culmination. Rather it is merely a liberalist improvement over the medievalist or feudalist social system (Desai, 1979a, 1979b: pp. 751-752).

A.R. Desai, as an intellectual Marxist peasant activist, suggests not to support socialist progressive democrats that keep bourgeoisie socialist democrats always in the political vanguard. In Pakistan's perspective social democratic program of Zulfiqar Bhutto with its socialist slogan of “Roti, Kapra, Makan” (Meal, Cloth, House), was just like erecting an "artificial Chinese Wall” (Desai, 1979a, 1979b: pp. 751-752) in the way towards the second stage of revolution, that is, socialism. After the independence of Pakistan and India from the international colonial forces, South Asian nations were led to bring about social equality on communal and religious basis. That did not seem to resolve the problem of the majority of South Asian population. Historical nations and nationalities kept demanding their recognition and rights. Neither that capitalism replaced the old feudalistic structure as the then Marxists had predicted, nor feudalistic system remained the same. Capitalism and feudalism, as well as socialism evolved into mixed and overlapping parallel socio-economic systems.

From the Marxist perspective, in case of Pakistan, the true Democratic revolution is yet to come as the slavelike agrarian economy still exists along with capitalist-feudalism, though it is assuming clearer capitalist mode gradually. Moreover, nationalities have yet to be recognized, industrialization, education and technology have to flourish, institutional corruption to be rid of. Till that occurs, socialist revolution led by the poor, the suppressed against the rich and the dominant, is not to occur.

Currently, Pakistani Marxists and leftist peasant activists of Sindh, following the international trends have diverged in to two different directions. One line, influenced by globalizing forces, following Trotskyist program to bring about revolution at international level. Other Marxist, rather leftist and center-leftist groups, following recent Marxist trend to reinterpret, understand and reform societies while simultaneously mobilize them for socialist revolution, seems to be erecting artificial “Chinese Wall” between two stages of revolution, predicted by Lenin. In Desai's words, they seem to have:

"come to the conclusion that the proletarian parties have to concentrate today on completing the first phase of the revolution by pressurizing the progressive bourgeoisie or by allying with them under the hegemony of the proletariat and completing the National Democratic or People's Democratic by strengthening the progressive national bourgeoisie, and thereby assist the process of generating an independent economic development on bourgeois lines, free from the trammels of imperialist and feudal forces.” (Desai, 1979a, 1979b: p. 754).

Marxists have very little faith in the capability of post-colonial civil society socialist reformists to bring about democratic and egalitarian changes in structure of the society.

They cannot industrialize their countries at a rate which would relieve the burden on the agrarian sector; they cannot develop at a tempo which would create conditions for a "take-off". They have neither the internal market, nor the external market to expand the economy at buoyant rate even by the yardstick of capitalism... They cannot resolve elementary problems like freeing the masses from semi-feudal forms of exploitation or solve the agrarian problem. The bourgeoisie of the Third World, product of belated, distorted colonial development have developed so "slothfully" and "cravenly" that while they felt the cramping effect of foreign capital and its direct and indirect political domination, "they were menacingly" faced by the proletariat and agrarian poor of the their own countries on whose plunder they thrived... Propertied classes of all types, including the most progressive national bourgeoisie in underdeveloped countries are instilled 
with "a mortal fear of expropriation and extinction” This fear has been driving all more or less privileged, more or less well-to-do elements in the newly independent Third World society in one "counter-revolutionary coalition” (Desai, 1979a, 1979b: pp. 755-756).

In Pakistan, such a mortal fear of losing the privileges, although not through socialist revolution, was evidenced during the murder of Benazir Bhutto, when Asif Ali Zardari, in the name of larger national interests, went against the Sindhi nationalist's sentiments and proclaimed "Pakistan Khappey" (We need united Pakistan). Although Sindhi masses were charged with Sindhi nationalist and anti-Pakistani sentiments, Zardaris leadership betrayed them to stave off the independence of Sindh and sustained alleged Punjabi-imperialism ${ }^{4}$ over them. By "Punjabi-imperialism, Sindhi-nationalists and Sindhi intellectuals" clearly mean the region of central Punjab, that constitute, areas of Lahore, Faisalabad and Sargodha, and the northern Punjab that includes Rawalpindi division, and Chakwal that make up bulk of Pakistan Army and the Pakistani establishment. Similarly, by being anti-Punjab, Sindhi ethno-nationalists do not mean to be against the province of Punjab, or Punjabi people. They are, in fact, against the political and administrative system in which one province, particularly its specific regions like central and northern Punjab, have been prioritized and are still being preferred to the disadvantage and marginalization of other ethnic minorities of Pakistan. Perhaps, deep in their hearts, Pakistani, feudal and capitalist politicians know very well that once the issue of rights of provincial and regional nationalities got resolved, masses will turn to them and would start demanding land and labour rights.

\section{Marxist Stance and the Internal Divisions within Sindhi Civil Society}

Classification of Sindhi Marxists and ethno-nationalists together as the civil society does not, however, liberates them from the internal divisions and contradictions. There are those who vociferously claim and organize themselves as civil society activists most of them working in NGO sector, and doing consultancies in International organizations and serving as media experts. Others mostly leftists and Marxists defy the label of civil society condemning it as the neo-primordialist bourgeoisie platform that is working to diminish the chances of radical revolutionary and structural change (Thalho, 2013; Sagar, 2010: p. 9).

Civil Society is also called as a "vocal class", which has been lampooned by the Sindhi Marxist as "chirping group", and existing civil society as the progeny of Joseph Goebbels, an anti-Semitic, hypocritical and virulent propaganda minister of Hitler's regime (Qadri, 2009: p. 22). Marxists try to critique civil society and liberalism basing their critique, definitions and its structure in the 18th century Renaissance, and 19th century rationalism. For them, civil society activism is counterproductive and instead of weakening of imperialistic forces, it leads to the strengthening of imperialistic forces. Generation of dialogue and debate in "public sphere" and its supposed incorporation into policy-making at regional and national level (Dahlberg, 2005) is believed to be the miscalculation. They believe that real struggle is the one which may bring about major fundamental structural change, and that such a change have come about in history when civil society or struggling classes have struggled for centuries, or when they have engaged in bloody civil wars (Qadri, 2009: pp. 22-23).

Marxist condemn civil society for its over-reliance on rationality, modernity and science, as they believe these are the notions churned by the "Empire", on which the foundation of real systemic or structural change cannot be erected. For Sagar (2010), rationality and science are not the alternatives to the Imperialist West and the Europe, but the rationality under the garb of civil society is the sustenance of it under new and different categories created by the West itself. Sagar, without mentioning any dependency theorist, uncritically lumps them up with the modernists. In his way of interpretation, critical theorists of "rationality", such as Jürgen Habermas who has critically theorized s the notion of rationality in terms of "Modernity as an unfinished project", also could not deserve to be mentioned by Sagar. Habermas had suggested the rationalization of life-world, which is less rational rather than irrational, to recouple the differentiated and distorted life-world and the system (Habermas, 1987). Habermas' theory of communicative action together with the understanding of his notion of public sphere is extremely crucial to understand the nature of civil societies in different societies (Habermas, 1984). Whereas, on the other hand, from the outset, for Sagar,"it would be silly to talk about social science without first acquainting oneself with Ronald Barthes" (Sagar, 2010: p. 16). Sagar has also opted to remain mum about the "ra-

\footnotetext{
${ }^{4}$ By "Punjabi-imperialism, Sindhi-nationalists and Sindhi intellectuals" clearly mean the region of central Punjab, that constitute, areas of Lahore, Faisalabad and Sargodha, and the northern Punjab that includes Rawalpindi division, and Chakwal that make up bulk of Pakistan Army and the Pakistani establishment. Punjabi imperialism or ruling classes are thought to be exploiting indigenous minority ethnicities, in collusion of the former U.P migrant class that dominates the state's bureaucracy and controls the urban centers of Sindh.
} 
tional" re-interpretation of social systems suggested by some of the well-recognized and leading neo-Marxist thinkers, who do not explain "criticism” as "total negation dialectically”, but instead pursue it like a psychoanalyst to slowly and gradually exorcise, by participating and critiquing institutions, forums, communities from within, instead of commenting on it by standing on the margins. Neo-Marxists emphasize the epistemological superiority of “social” relations of productions over the “economic” relations of productions (Žižek, 2012; Eagleton, 2011).

In his singular attack on rationality, Sagar even misses many critical thinkers, for whom "rational as real, or real as rational' way of reasoning bears little meaning, as for example, for Bourdieu, "what is real is relational” (Bourdieu, 2003), not rational. Sagar is also complete in his indifference to post-developmentalist epistemologies and movements that have emerged in South America, that have practically negated Western-led development model and have replaced it with indigenous localized notions like Buen Vivir and Sumak Swami (Gudynas, 2013; Gudynas, 2011; Lang, 2013; Pearson, 2009; Escobar, 2012), that are not at all Western-rational in the sense in which Sagar has condemned rationality. Even within west there have emerged anti-capitalist trends like “degrowth" that seem totally "irrational” in modernist terms. Sagar's lack of compromise with any middle roader is total, and one tempts to fit him into the "category" of Marxists that fit clearly into the left-of center position if not far-left. While much of his analysis is of critical value in itself, it can serve as a useful sensitizing critical starting point for any researcher in Pakistan and Sindh.

Yet most of Sindhi Marxist criticism of nationalism in South-Asian perspective, and particularly his criticism of the civil society as Bourgeoisie category and forum of “corporate intellectual market” (Sagar, 2010: p. 15; Qadri, 2009) is highly pertinent and seems plausible in the current scenario. Civil society, at least in Sindh, as it stands seems very much like “corporate intellectual market’s prop”, in which only NGOs heads and some stray ethno-nationalists seem to be welcome participants and commenters, whereas Sindhi Marxist, due their very negation of the notion of civil society, do not participate in civil society gatherings and indoor meetings. Moreover, Sindhi intellectuals belonging to different schools of thought, religious leaders, peasant activists, senior citizens, retired bureaucrats, secretaries, lawyer leaders, workers' unionists, tribal chiefs, representatives of the mainstream parliamentary parties, former ministers, writers, poets, educationists, academic researchers and scientists remain, by and large, indifferent to civil society meetings and conferences.

Sagar and some most other Sindhi Marxist writers define civil society as a social group (Sagar, 2010; Qadri, 2009), but, probably by its very structure, civil society does not qualify itself to the level of group. Civil society in Sindh, for instance, is an amorphous and arbitrary aggregate of likeminded reformist activists that are always ready to get together on short notice to debate and discuss certain ill-defined issues and set up half-hearted ill organized action plans. And in case of political organizations, almost all Sindhi ethno-nationalist parties have recruits from rural peasant families and have formed peasant-activist organizations though most of such organizations are merely on paper only and do not have any real existence.

Although Marxists condemn the working and ideologies of other political and social organizations, yet they do protest together with them on issues that do not conflict with ideology. For instance, Marxists protest against sectarian violence, and in case of forced conversions, kidnapping and raping of Dalit girls such as Kasturi Kolhi, or Hindu women such as Rinckle Kumari, a Marxist Awami Workers Party protested on April 17, 2013, in front of Hyderabad Press Clud, together with "Labour Party Pakistan (LPP), Communist Party (CP), Jeay Sindh Mahaz (JSM), Women Action Forum (WAF), Sindh Youth Network (SYN) and Progressive Youth Forum (PYF) joined the demo" (Progressive Youth Forum, 2012).

Ethno-nationalist leftist parties such as Awami Tehreek are alleged by Marxists to be apologetic, and in turn Awami Thereek, an avowedly progressive leftist party criticizes other hardline Sindhi ethno-nationalist parties and organizations that rigidly follow G.M. Sayed's ideology, as rather conservative and primordial in outlook. Awami Tehreek probably seems justified there as almost all factions of JSQM are expressly fanatical in their commitment to Sayed's philosophy. G.M. Sayed's writings are no less than holy and sacred revelations for them. They are least interested in reinterpreting primordial history and have not seriously updated Sayed's manifesto to any significant level in the changed context. Nor are they apprehensive, inclusive and accepting of local transnational and global discourses that are and to a considerable degree have greatly changed the fundamental structure of Sindhi society. Their conservatism seems to resemble those on whose negation Sayed's philosophy stands. In that sense, they fare no better than shrine worshippers of Bhitai and Qalandar whom Sayed has thoroughly condemned. They have however, seem to have maneuvered politically on trifle egoistic issues that has led nothing substantial than the division of original JSM into several factious political groups. Leftist eth- 
no-nationalist's Pakistan-centric and anti-Punjab focus has not allowed them to fix loopholes within the Sindhi society, and resultantly they are groping in the dark to resolve cultural, ethnic, religious and economic contradictions within the rural society of Sindh.

According to a Marxist thinker "Marxism may no longer have any solution ready to hand but its critical edge is not necessarily blunted.” (Therborn, 2008: p. 110). Marxism as a methodology and as a theoretical approach to understand and intervene in ethnic peasant communities can greatly serve the purpose of bringing about positive socio-economic change at communal and regional level. A longitudinal Marxist ethnographic enquiry of ethnically marginalized peasant communities of Sindh, where Marxists have been active, can help clarify misconceived political strategies through "empirical refutation", and help in "theoretical reconstruction" of the contextualized Marxist action-agenda. Burawoy (1996) has stressed on the use of comparative extended ethnographic method, requiring participant observation,

“... that grounds the messianic imagination and restrains the intellectual conceit of illusory universality. It is a method that demands extended participation in time and space to comprehend real-life processes, in order to grasp the projects of the participant and not just those of the observer. It is also a method that extends beyond the everyday world of projects to their external conditions of existence, while never forgetting that those conditions are not natural and immutable but themselves historical products that require reproduction” (Burawoy, 1996: p. 98).

Ideally, there is little wrong with the Marxist interpretations of castes and communities. Their analysis probably goes disarrayed when, hurriedly they spill out wishful unilateral verdicts on complex metonymic realities of life. According to them castes and Bradaris are essentially patriarchal structures that suppress and control women sexuality and love to preserve the economic and cultural hegemony of the dominant classes, castes, tribes and the whole tribal and communal structure. Yet they are unable satisfactorily explain the historical, contextual value-laden reality of the "love", community, socialism, dialectics and "historicity" itself. Instead of wholesome rejection of the tribal and communal reality as patriarchal, anti-socialist, or exploitative, they should also condescend to look into these lived social realities whatever little good they contain. Ideal goals are always attractive and luring to strive for. Same is true of socialist principles, but while actively engaging with any community or caste or tribe, a pragmatist socialist cannot bypass or ignore the tribal-casteist reality.

Slavoj Žižek, himself a prominent contemporary Marxist, suggests the reversal of Marxist formula, "Philosophers have only interpreted the word, the point is to change it". He maintains that Marxists, in twentieth century, in fact, "tried to change the world too quickly. The time is to interpret it again and start thinking” (Žižek, 2012). He doesn't mean by "start thinking” to just keep thinking and do not at all act to change. He stresses that it is not desirable under circumstances to struggle outright for the radical revolutionary change, the chances of whose materialization are probably be very little. According to Zizek:

The beauty is to select a topic which touches the fundamentals of our ideology, but at the same we could not be accused of promoting an impossible agenda like abolition of private property, but something that can be done and done relatively successfully. We should carefully select an issue to stir up a public debate and then we cannot be accused of being utopians in that sense of the term (Žižek, 2012).

\section{Civil Society’s Efforts for Land Reforms and Macro-Level Structural Changes}

Civil Society Intelligentsia, particularly, based in urban areas of lower Sindh such as Hyderabad, Tando Allahyar and Mirpurkhas, has delved upon the possibility of land reforms and given its undeclared verdict against such reforms. The fact is worth mentioning here that there is currently going on a serious kind of internal dialogue in rural-urban public sphere between pro-land reform activists and the majority civil society intelligentsia, which believes that land reforms to snatch lands to redistribute among landless peasants is either impractical, or inconsequential. They believe that intra-familial distribution of land due to increase in population and family size, landed property is continually being divided among newly formed families. Basing their argument on that fact they predict that within coming three to four decades, the demand for land reforms would automatically lose its significance. Therefore, they suggest peasant activists to wait and watch. On the other hand, mainstream peasant activist still staunchly support the land reforms believing that it is inhuman and criminal even to think like, "waiting for the inevitable". Exploitation and inequality cannot be waited out to vanish by itself.

Currently the agendas of peasant activist organizations which are linked to and make up rural-urban civil so- 
ciety strata, are framed more in line with leftist-Marxist interpretations (Bhandar \& Oxfam, 2012) that do not bring specific structurally exploited tribal-communal Dalit or lower caste peasant groups into relief. Nevertheless, the most of peasant activists seem to be apprehensive of the different socio-economic and cultural contexts of peasants of different sub-regions within Sindh, and, therefore, want to introduce context-apprehensive clauses in Sindh Tenancy Act, and Bonded Labor Abolition Act (Maliha, Razzaq, \& Shazreh, 2004; PILER, 2010). Civil Society activists and NGOs mainly have focused on land reforms, macro-structural changes, legal and constitutional provisions for peasants and have advocated corporate growth model for agricultural development. They are however, lacking in their focus on micro-development of peasant communities, ethnic and religious peasant minorities and the possibilities of cooperative community driven development projects.

\section{Conclusion}

Sindhi civil society is the micro-society that asserts itself with the assistance of NGOs, or development activists. Sindhi civil society is going through the depressive phase of its evolution in which it finds itself marginalized and suppressed. Some of the NGO activists that form the bulk of the civil society activists of rural Sindh, harbor strong feelings of hatred towards predominantly Pashtun NGO elite and the allegedly Punjab-dominated ethnically discriminatory "Pakistani civil society". Nevertheless, majority of NGO activists of Sindh and Sindhi activists working in NGO sector are socially and politically active in their self-created public sphere, and try to cooperate and collaborate with all Sindhi NGOs, Sindhi social activists and Sindhi political activists to form the united front against the powerful feudals, establishment, government and the state institutions. Sindhi civil society does not recruit angel-like figures in its cadre, and share all kinds of social pathologies that are commonly found in any other civil society and its interesting NGO-based organizations. It is donor-dependent, economically dependent on funding from international and multilateral transnational donor agencies, and plays all sorts of technical tricks to seek projects for the sake of projects and money-making. Despite all that it's committed to the core Sindhian agenda that is to safeguard the rights of Sindhi ethnic community on priority basis. Yet, they seem to be far away from succeeding in their so called community-based management projects. They think that the whole development issue revolves around mismanagement and bad governance at the top that could be resolved through technical and managerial adjustments without seeking any kind of political solutions. Hence, theirs is, in fact, the depoliticizing exercise that reduces the "political" to "technical". Political empowerment of the local communities, the common ruralite or a peasant, is nowhere on their development agenda. It is saddening to note that there is not even any development indicator in Pakistan government's and UNDP's development measurement scale that may specifically measure the political empowerment and decision-making capabilities of the local village and ethnic communities. It, in itself, is indicative of the hypocrisy and unwillingness of the outside developers, and their underestimation of the capabilities of local communities to decide, launch, monitor and run local community-based projects. Sindhi Marxists, probably very much like any other Marxist in Pakistan, are also extremely suspicious of civil society as change agent.

For Sindhi Marxists, as well for Sindhi nationalists, Sindhi NGO elite and Sindhi social activists, it would serve better to engage with ethnic communities on more intimate level. Instead of merely focusing on abstract notions of change or development, those social activists that are sincere to their humanitarian and political cause, should actively engage themselves with local people, peasant communities, ethnic minorities, and marginalized caste-groups, to get themselves out of self-depressing situations. They should engage themselves with contextual organic processes of actual Sindhi society. They should revisit their ideal stances and ideological underpinnings and return back to reinterpretation of socio-economics of rural life, understanding of ethnic reality of Sindhi communities and, for that matter, Sindhi society.

\section{References}

Ahmed, I. (2013). Irfan Ahmed. Aljazeera.

http://www.aljazeera.com/indepth/features/2013/12/pakistani-ngos-fear-new-constraints-20131231991895761.html

Ahmed, N. (2009). Role of NGOs in Pakistan. http://theroleofngosinpakistan.blogspot.com/

Anonymous (2013). Role of NGOs and Civil Society in Peasant Activism.

Aristotle (1252). Politics (Vol. Bk 1 passim).

Bagci, C. (2003). Historical Evolution of NGOs: NGO Proliferation in the Post-Cold War Era. Avrupa Gunlugu, 299-326. 
Bhandar, H. S., \& Oxfam, G. B. (2012). People’s Declaration of Agrarian Reforms. Pamphlet. Hyderabad: Bhandar Hari Sangat.

Bourdieu, P. (2003). Outline of a Theory of Practice. Cambridge: Cambridge University Press.

Burawoy, M. (1996). From Capitalism to Capitalism via Socialism. ILWCH (Fall), 77-99.

Chandio, J. (2013). Jaaizo (Talk Show on Sindh TV). Sindh TV. Karachi.

Cohen, J. L. (1994). Civil Society and Political Theory. Cambridge, MA: MIT Press.

Dahlberg, L. (2005). The Habermasian Public Sphere: A Specification of the Idealized Conditions of Democratic Communication. Studies in Social and Political Thought, 1-18.

Desai, A. R. (1979a). The “Two-Sages” Theory of Revolution in the Third World: Need for Its Evaluation. In A. R. Desai, \& A. R. Desai (Ed.), Peasant Struggles in India. Bombay: Oxford University Press.

Desai, A. R. (1979b). Unconventional Anthropology of “Traditional” Peasantry. In A. R. Desai, \& A. R. Desai (Ed.), Peasant Struggles in India. Bombay: Oxford University Press.

Eagleton, T. (2011). Why Marx Was Right. London: Yale University Press. http://ashoub.persiangig.com/books/TerryEagleton-WhyMarxWasRight.pdf/download

Escobar, A. (1995). Encountering Development: The Making and Unmaking of Third World. Princeton, NJ: Princeton University Press.

Escobar, A. (1997). Antrhropology and Development. In UNESCO. Oxford: Blackwell Publishers.

Escobar, A. (2012). Alternatives to Development: An Interview with Arturo Escobar. Venice.

Gudynas, E. (2011). Buen Vivir: Today’s Tomorrow. Development, 54, 441-447. http://dx.doi.org/10.1057/dev.2011.86

Gudynas, E. (2013). Debates on Development and Its Alternatives in Latin America: A Brief Heterodox Guide. In M. D. Mokrani (Ed.), Beyond Development: Alternative Visions from Latin America. Quito-Ecuador: Transnational Institute/ Rosa Luxemburg Foundation.

Habermas, J. (1984). Reason and the Rationalization of Society (Vol. 1). Boston, MA: Beacon Press.

Habermas, J. (1987). Lifeworld and System: A Critique of Functionalist Reason (Vol. 2). Boston, MA: Beacon Press.

International Finance Corporation (2011). International Financial Institutions and Development through Private Sector. A Joint Report of 31 Multilateral and Bilateral Development Finance Institutions (p. 80). Washington DC: International Financial Corporation. http://www.miga.org/documents/IFI_report_09-13-11.pdf

Keane, J. (2009). Civil Society, Definitions and Approaches. http://johnkeane.info/media/pdfs/jk_civil_sciety_definitions_encyclopedia.pdf

Lang, M. (2013). The Crisis of Civilisation and Challenges for the Left. In M. Lang, \& D. Mokrani (Eds.), Beyond Development: Alternative Visions from Latin America (p. 195). Quito-Ecuador: Transnational Institute/Rosa Luxemburg Foundation.

Maliha, Razzak, \& Shazreh (2004). Bonded Labor in Agriculture: A Rapid Assessment in Sindh and Baluchistan, Pakistan. International Labour Organisation. Geneva: Internationa Labour Office.

Pearson, T. (2009). Opinion and Analysis: Law and Justice/Participation. http://venezuelanalysis.com/analysis/4980

PILER (2010). Labor Rights in Pakistan, Declining Decent Work and Emerging Struggles. Pakistan Institute of Labour Education and Research.

Powell, F. W. (2007). The Politics of Civil Society: Neoliberalism or Social Left? Bristol: Polity Press.

Progressive Youth Forum (2012). Progressive Youth Forum Pakistan. http://thepyfpakistan.wordpress.com/page/4/

Qadri, S. (2009). Civil Society: Hik Marxis Tajziyo. Aadarsh, 20-48.

Qazi, A. (2013). Tabdeeli Jo Safar: Dehli Sindh Khaan Agtey. Daily Kawish.

Sagar. (2010). Pakistan: History on the Run. Lahore: Good Books.

Shah, Z. (2014). Personal Reflection: Politics of Development and Civil Society of Pakistan. Merinews. http://www.merinews.com/article/personal-reflection-politics-of-development-and-civil-society-of-pakistan/15893763.sht $\underline{\mathrm{ml}}$

Siddiqa, A. (2014). Islands in the Sand. The Express Tribune. http://ribune.com.pk/story/656506/islands-in-the-sand/

Stefan, Z. P. (2008). Tocqueville on Civilian Society: A Romantic Vision of the Dichotomic Structure of Social Reality. Archiv für Begriffsgeschichte (Felix Meiner Verlag).

Thalho, B. (2013). Sindhi Civil Society.

Therborn, G. (2008). From Marxism to Post-Marxism? London: Verso. 
Zaidi, S. A. (1999). NGO Failure and the Need to Bring Back the State. Journal of International Development, 11, $259-271$. Žižek, S. (2012). Slavoj Žižek: Don’t Act. Just Think.

http://www.dailymotion.com/video/xz3o3y_slavoj-zizek-don-t-act-just-think_tech 
Scientific Research Publishing (SCIRP) is one of the largest Open Access journal publishers. It is currently publishing more than 200 open access, online, peer-reviewed journals covering a wide range of academic disciplines. SCIRP serves the worldwide academic communities and contributes to the progress and application of science with its publication.

Other selected journals from SCIRP are listed as below. Submit your manuscript to us via either submit@scirp.org or Online Submission Portal.
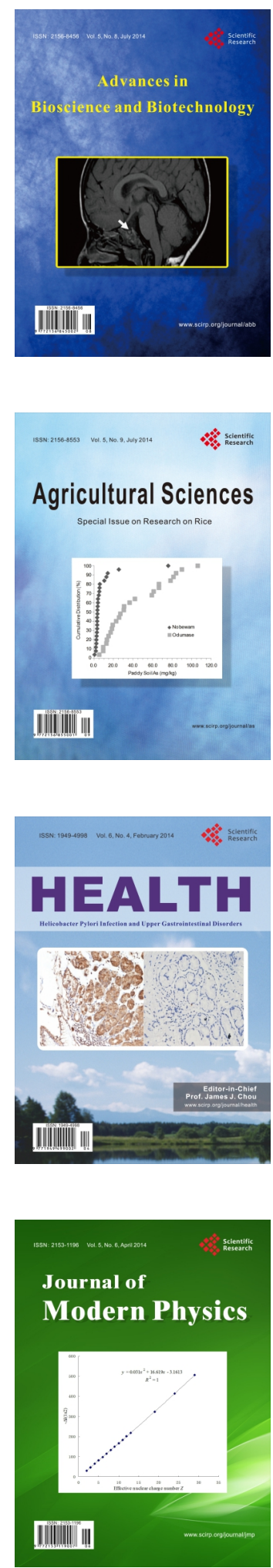
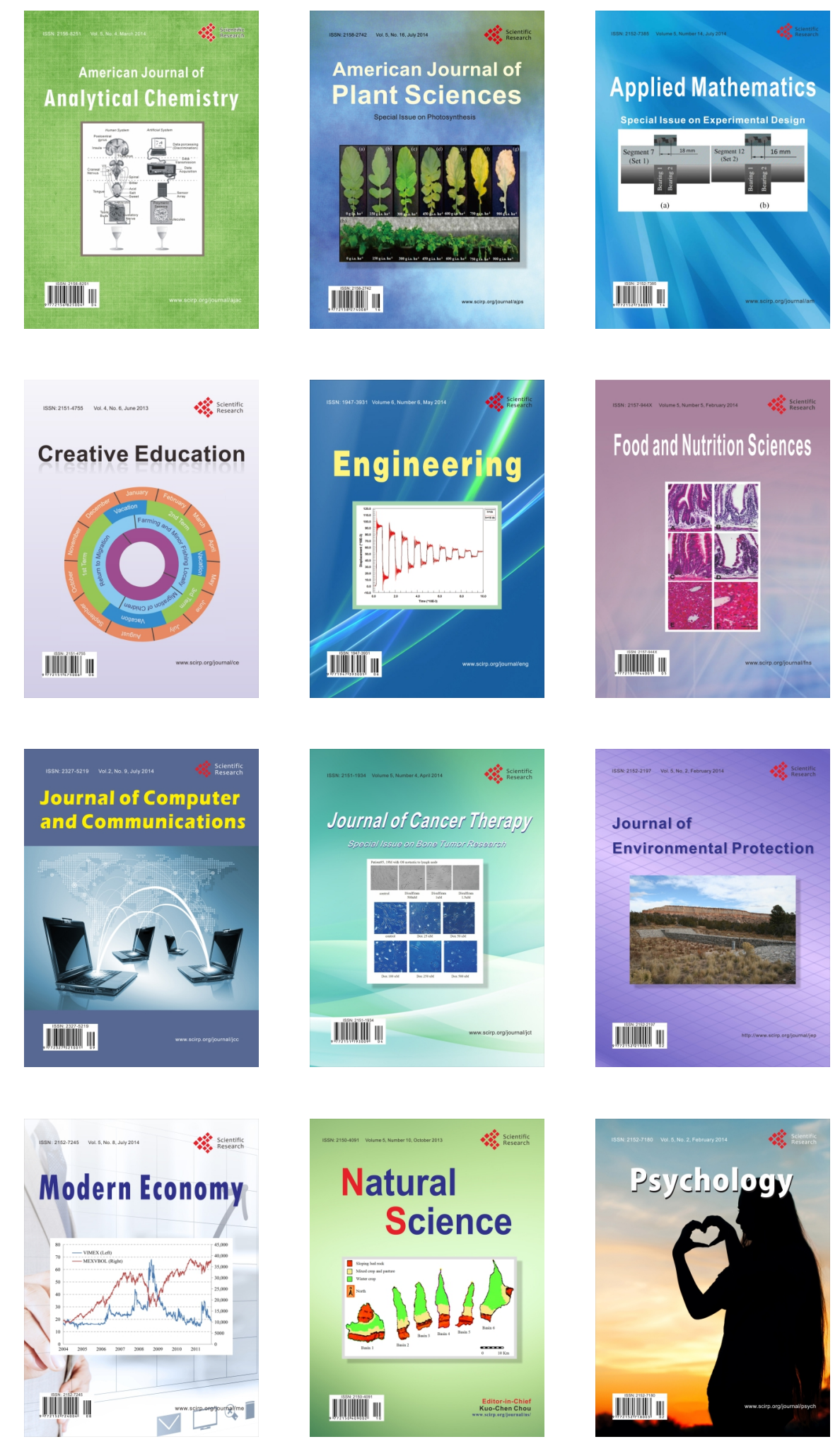